\title{
Training System and Vine Spacing Impact Vine Growth, Yield, and Fruit Composition in a Vigorous Young 'Noiret' Vineyard
}

\author{
Justine E. Vanden Heuvel ${ }^{1,3}$, Steven D. Lerch ${ }^{1}$, \\ Celine Coquard Lenerz ${ }^{2}$, James M. Meyers ${ }^{1}$, \\ and Anna Katharine Mansfield ${ }^{2}$
}

\begin{abstract}
AdDitional INDEX wORDs. Vitis hybrids, crop load, wine preference
Summary. An experimental vineyard was planted in Geneva, NY, in 2007 to determine the impact of training system [low bilateral cordon with vertical shoot positioning (LVSP), high wire bilateral cordon (HWC)], vine spacing (1.8 and $2.4 \mathrm{~m}$ ), and root system [own-rooted, grafted onto '101-14 Mgt' (Vitis riparia $\times$ Vitis rupestris)] on vine growth, yield, fruit composition, and wine quality of the recently-released winegrape 'Noiret' ( Vitis hybrid). Yield components were generally unaffected by training system in 2009 , but vines spaced at $2.4 \mathrm{~m}$ had about six fewer clusters per meter of canopy, lower pruning weights by $0.24 \mathrm{~kg} \cdot \mathrm{m}^{-1}$, and clusters that were $0.01 \mathrm{~kg}$ greater in mass compared with vines spaced at $1.8 \mathrm{~m}$. In 2010 , HWC yielded $0.98 \mathrm{~kg} \cdot \mathrm{m}^{-1}$ more than LVSP, and had a higher crop load ratio by 0.8 . Larger vine spacing increased yield by $0.32 \mathrm{~kg} \cdot \mathrm{m}^{-1}$ and increased crop load ratio by 0.3 . Grafted vines increased yield by $0.36 \mathrm{~kg} \cdot \mathrm{m}^{-1}$ and crop load ratio by 0.3. Training system and vine spacing had minimal impact on fruit composition in both years. Rank sum analysis indicated a consumer preference for the aroma of wines from the HWC/2.4-m treatment compared with wines from the LVSP/ 1.8-m treatment in 2009, and a consumer preference for the aroma of wines from the HWC/1.8-m treatment compared with wines from the LVSP/1.8-m treatment in 2010. Results suggest that the LVSP system is not a suitable choice for vigorous 'Noiret' vines because of low yields, low crop load ratios, and low preference rankings of LVSP wines by the consumer sensory panel.
\end{abstract}

$\mathrm{N}$ oiret', an interspecific red hybrid winegrape released by Cornell University in 2006, produces varietal wines with moderate tannin structure that lack hybrid character (Reisch et al., 2006). Vine growth habit was originally described as semiupright to semitrailing, and the cultivar has been reported to produce lower yield than 'Concord' (Vitis labruscana) with an average yield over a 10 -year period of $5.6 \mathrm{~kg} /$ vine $\left(2.7 \mathrm{~kg} \cdot \mathrm{m}^{-1}\right)$ compared with $7.6 \mathrm{~kg} /$ vine $\left(3.6 \mathrm{~kg} \cdot \mathrm{m}^{-1}\right)$ for 'Concord'. Average pruning weight over the same period was $1.5 \mathrm{~kg} /$ vine $\left(0.71 \mathrm{~kg} \cdot \mathrm{m}^{-1}\right)$ in 'Noiret' compared with $2.0 \mathrm{~kg} /$ vine $\left(0.95 \mathrm{~kg} \cdot \mathrm{m}^{-1}\right)$ for

The project was funded by the Viticulture Consortium East and the Lake Erie Regional Grape Program.

The authors thank Luann Preston-Wilsey and Pamela Raes for their technical assistance, Bruce Reisch and Steve Luce for advice on growing 'Noiret', and Peter Cousins and Susan Brown for comments on the manuscript

${ }^{1}$ Department of Horticulture, Cornell University, Geneva, NY 14456

${ }^{2}$ Department of Food Science, Cornell University, Geneva, NY 14456

${ }^{3}$ Corresponding author. E-mail: jev32@cornell.edu.
'Concord' (Reisch et al., 2006) when grown on 2.1 -m vine spacing.

While many growers are interested in planting 'Noiret', there is little research to provide guidance as to the appropriate viticultural practices for this cultivar. It is unclear whether vines of 'Noiret' should be own-rooted or grafted because of questions of winterhardiness, phylloxera (Daktulosphaira vitifoliae) susceptibility, and vine size (Reisch et al., 2006). Growers in New York have planted 'Noiret' own-rooted, or grafted onto rootstocks, such as '101-14 Mgt', '3309C' (Vitis riparia $\times$ Vitis rupestris), and 'Riparia Gloire' ( V. riparia). Questions also remain concerning the appropriate selection of training system and vine spacing. Reported observations of vine growth in Geneva, NY (Reisch et al., 2006), were based on plantings of vines growing at $2.1-\mathrm{m}$ spacing on a cane-pruned umbrella kniffin system. Lacking specific recommendations, growers in the Finger Lakes region of New York have planted 'Noiret' on a variety of training systems [low cordon with vertical shoot positioning, umbrella kniffin, high wire cordon] with vine spacing ranging from 6 to $9 \mathrm{ft}$ $(1.8$ to $2.7 \mathrm{~m})$. Anecdotally we are aware of growers who, as a result of high vigor, have removed every other vine of original plantings so that spacing is as great as $16 \mathrm{ft}(4.9 \mathrm{~m})$ between vines.

Because of the recent release of this cultivar, there is little information available on best management practices. The objective of this study was to investigate the impact of training system, vine spacing, and rootstock on vine growth, yield components, fruit composition, and consumer preference for 'Noiret' wines produced from a young vineyard.

\section{Materials and methods}

V I N E Y A R D S I T E A N D EXPERIMENTAL DESIGN. The planting was established at the New York State Agricultural Experiment Station in Geneva, NY, in 2007 with dormant $\mathrm{l}$-year-old vines in a block with deep, well-drained Honeoye fine silt loam (fine-loamy, mixed, semiactive, mesic Glossic Hapludalfs). Rows were spaced $9 \mathrm{ft}$ apart and oriented north-south. The experiment was designed as a $2 \times$ $2 \times 2$ split-split plot design with five replications. The treatments were training system as the main plot (HWC vs. LVSP) (Reynolds and Vanden Heuvel, 2009)), vine spacing as the subplot

\begin{tabular}{llll}
\hline $\begin{array}{l}\text { Units } \\
\text { To convert U.S. to SI, } \\
\text { multiply by }\end{array}$ & U.S. unit & SI unit & $\begin{array}{l}\text { To convert SI to U.S., } \\
\text { multiply by }\end{array}$ \\
\hline 29.5735 & $\mathrm{fl} \mathrm{oz}$ & $\mathrm{mL}$ & 0.0338 \\
0.3048 & $\mathrm{ft}$ & $\mathrm{m}$ & 3.2808 \\
3.7854 & $\mathrm{gal}$ & $\mathrm{L}$ & 0.2642 \\
2.54 & $\mathrm{inch}(\mathrm{es})$ & $\mathrm{cm}$ & 0.3937 \\
0.4536 & $\mathrm{lb}$ & $\mathrm{kg}$ & 2.2046 \\
1.4882 & $\mathrm{lb} / \mathrm{ft}$ & $\mathrm{kg} \cdot \mathrm{m}^{-1}$ & 0.6720 \\
0.001 & $\mathrm{ppm}$ & $\mathrm{g} \cdot \mathrm{kg}$ & 1000 \\
0.001 & $\mathrm{ppm}$ & $\mathrm{g} \cdot \mathrm{L}^{-1}$ & 1000 \\
1 & $\mathrm{ppm}$ & $\mathrm{mg} \cdot \mathrm{L}^{-1}$ & 1 \\
$\left({ }^{\circ} \mathrm{F}-32\right) \div 1.8$ & ${ }^{\circ} \mathrm{F}$ & ${ }^{\circ} \mathrm{C}$ & $\left({ }^{\circ} \mathrm{C} \times 1.8\right)+32$
\end{tabular}


(1.8 vs. $2.4 \mathrm{~m}$ ), with root system (own-rooted vs. grafted on '101-14 Mgt') randomized among the subplots. Panels were $7.2 \mathrm{~m}$ in length and contained either three or four vines depending on the vine spacing treatment. Two contiguous panels comprised an experimental unit, for a total of either six or eight vines per experimental unit depending on spacing treatment. A panel of guard vines was planted at the end of each row. Drip irrigation was installed in the planting, and was used periodically through 2007 and 2008 to ensure continued vine growth. All planted vines survived and were established on the training systems by Sept. 2008 . In early 2009 vines were pruned to 15 nodes per meter of canopy, while in 2010 vines were pruned to 18 nodes per meter of canopy. Because of the significantly smaller size of the ownrooted vines, data were collected on grafted vines only in 2009 , but on all data vines in the experiment in 2010.

YIELD COMPONENTS. Fruit from each vine was hand-harvested when fruit $\mathrm{pH}$ was nearing 3.6 (4 Nov. 2009, 22 Oct. 2010). Yield per vine was quantified using a hanging scale (Salter Weigh-Tronix, Fairmont, MN), and cluster number per vine was recorded. Average cluster weights were calculated by dividing yield by cluster number on a per vine basis. A random sample of 20 clusters per experimental unit was collected at harvest and stored at $-40{ }^{\circ} \mathrm{C}$ until analysis. Vines were pruned during the winter and pruning weights were collected on a per vine basis in each data panel. Crop load ratio was calculated by dividing yield by pruning weight on a per vine basis.

CANOPY ANALYSIS. Enhanced point quadrat analysis [EPQA (Meyers and Vanden Heuvel, 2008)] was used to characterize canopy growth and microclimate in 2010. A narrow metal rod was inserted into the canopy at $20-\mathrm{cm}$ intervals and successive contacts of leaves, clusters, and canopy gaps were recorded as the rod was pushed through to the other side of the canopy. Canopy parameters were analyzed by EPQA and Calibrated Exposure Mapping Tools [version 1.6 (J.M. Meyers, unpublished data].

Frutt COMPOSITION. The 20-cluster sample was thawed at room temperature, crushed by hand, and the slurry pressed through cheese cloth to yield a juice sample. Soluble solids were measured using a temperaturecompensated refractometer (Abbé; ATAGO, Bellevue, WA), $\mathrm{pH}$ was measured using a $\mathrm{pH}$ meter (Orion 3-Star; Thermo Fisher Scientific, Waltham, MA), and titratable acidity (TA) was determined as tartaric acid equivalents on a $10-\mathrm{mL}$ juice sample by autotitration (Digital Buret ${ }^{\mathrm{TM}}$; BrandTech Scientific, Essex, CT) using 0.1 M sodium hydroxide to an endpoint of pH 8.2.

Winemaking. Field replicates of each grafted treatment (grafted $\mathrm{HWC} / 1.8 \mathrm{~m}$, grafted HWC/2.4 m, grafted LVSP/1.8 m, grafted LVSP/ $2.4 \mathrm{~m}$ ) were combined and then separated into two lots for replicated fermentations of each field treatment (fora total of eight fermentations in each year). Fruit was destemmed, crushed, and treated with $50 \mathrm{mg} \cdot \mathrm{L}^{-1}$ sulfur dioxide added as potassium metabisulfite. Diammonium phosphate [DAP (Presque Isle Wine Cellars, PA)] was added at a rate of $1 \mathrm{~g} \cdot \mathrm{kg}^{-1}$, Fermaid K (Lallemand, Rexdale, ON, Canada) at $0.1 \mathrm{~g} \cdot \mathrm{L}^{-1}$ and Goferm (Lallemand) at $0.15 \mathrm{~g} \cdot \mathrm{L}^{-1}$ in 2009. In 2010, yeast assimilable nitrogen was measured and all lots found to be over $200 \mathrm{mg} \cdot \mathrm{L}^{-1}$, so no nitrogen supplement was added beyond the GoFerm Protect (at $0.3 \mathrm{~g} \cdot \mathrm{L}^{-1}$ ) at yeast rehydration. The must was brought to $20{ }^{\circ} \mathrm{C}$ and inoculated with yeast ICV-GRE (Lallemand) to $0.27 \mathrm{~g} \cdot \mathrm{L}^{-1}$. Fermentation was performed with skin contact in 114-L jacketed stainless steel fermenters with automated temperature control. During the first $3 \mathrm{~d}$ of alcoholic fermentation, the must was warmed slowly from $20^{\circ} \mathrm{C}$ to a maximum between 30 to $35^{\circ} \mathrm{C}$, after which the temperature was held at $\approx 25$ to $30{ }^{\circ} \mathrm{C}$. Cap management consisted of manual punch-down performed twice daily throughout fermentation. When residual sugar reached $<0.5 \%$ as measured by Clinitest tablets (Bayer, Etobicoke, ON, Canada), wines were dejuiced, racked into standard 5-gal glass carboys, and inoculated with Alpha (Lallemand) to start malolactic fermentation (MLF). Upon completion of MLF, potassium metabisulfite was added to maintain $40 \mathrm{mg} \cdot \mathrm{L}^{-1}$ free sulfur dioxide. Wines were cold stabilized at $2^{\circ} \mathrm{C}$. In 2009 , titratable acidity was adjusted to 6.5 $\mathrm{g} \cdot \mathrm{L}^{-1}$ through addition of potassium carbonate before cold stabilization; in 2010 , the same acid level was achieved with the addition of tartaric acid postcold stabilization. Before bottling in standard, $750-\mathrm{mL}$ glass bottles (antique green, Saint-Gobain, Courbevoie, France) an expert panel $(n=6)$ screened the wines for faults and judged the fermentation replicates for each treatment to be similar. Bottling and screwcapping were performed manually.

Consumer Wine preference. For each vintage, wines produced from the four grafted treatments were compared through preference ranking (Kramer, 1956), using the difference in preferential rank sums between all possible treatment combinations to overcome the deficiencies of the original method (Joanes, 1985). Twentysix sensory panelists ( 15 female, 11 male), ranging in age from 21 to 61 years (mean 38 years), were selected from a list of volunteer subjects maintained by the Cornell Enology Extension Laboratory based on their availability and frequency of red wine consumption; 18 panelists reported consuming red wine at least two to three times per month, and the remaining panelists consumed red wines at least once per month. As we were not interested in preferences for one vintage over another, wines produced in 2009 and 2010 were evaluated in two separate flights of four wines each; each panelist evaluated both flights during a single session, with a 5-min break between flights. Wines from both vintages were evaluated over $2 \mathrm{~d}$ during late July and early Aug. 2011.

Panelists were seated in sensory booths, and were presented with 30-mL samples of each wine, served at room temperature in $300-\mathrm{mL}$ ISO tasting glasses labeled with threedigit random numbers and covered with petri dish lids. Wine serving order was randomized within and across participants. Panelists were asked to smell all the samples before indicating aroma preference by ranking wines from one (most favored) to four (least favored). Wines were not ranked for gustatory properties, as sensory screening and chemical analysis including acid quantification and profiling suggested that gustatory properties were not widely variable.

Statistical analysis. Treatment response data for vine performance and canopy architecture were analyzed using the mixed model (MIXED) procedure of SAS (version 9.3; SAS 
Institute, Cary, NC). Years were analyzed separately because of the inclusion of rootstock as a treatment in only 1 of the 2 years of the study. Probability values for comparison of treatment means were computed for both main effects and interactions using LSMEANS. Significance of sensory data were determined using the rank sums critical values tables (Basker, 1988).

\section{Results}

Yield COMPONENTS AND VINE GROWTH. Yield per meter of canopy was unaffected by training system or vine spacing in 2009, although cluster number was reduced by 6.1 clusters $/ \mathrm{m}$ in the $2.4-\mathrm{m}$ spacing treatment, and average cluster weight was slightly increased by $0.01 \mathrm{~kg}$ in the $2.4-\mathrm{m}$ spacing treatment compared with the 1.8-m treatment (Table 1). Pruning weight was $0.24 \mathrm{~kg} \cdot \mathrm{m}^{-1}$ greater in the $1.8-\mathrm{m}$ treatment than in the 2.4-m treatment (Table 1). Crop load ratio values were not impacted by treatment and averaged from 3.5 to 4.0 .

In 2010, vines in the HWC system produced $\approx 1 \mathrm{~kg} \cdot \mathrm{m}^{-1}$ more fruit than vines growing in the LVSP system through an increase in average cluster weight of $0.06 \mathrm{~kg}$ (Table 1 ). Crop load ratio decreased from 3.9 to 1.9 in the LVSP system between 2009 and 2010, while crop load ratio in the HWC treatment decreased from 3.5 to 2.7 between seasons (Table 1 ). Yield was $0.32 \mathrm{~kg} \cdot \mathrm{m}^{-1}$ greater in vines spaced at $2.4 \mathrm{~m}$ compared with those spaced at $1.8 \mathrm{~m}$, through an increase in average cluster size of $0.02 \mathrm{~kg}$. Pruning weight was $0.16 \mathrm{~kg} \cdot \mathrm{m}^{-1}$ greater in the HWC treatment (Table l) compared with the LVSP treatment. Grafted vines produced $0.36 \mathrm{~kg} \cdot \mathrm{m}^{-1}$ more fruit compared with own-rooted vines through an increase in average cluster weight of $0.02 \mathrm{~kg}$ (Table 1 ).

Training system had a significant impact on all EPQA metrics in 2010 (Table 2). Occlusion layer number [OLN (number of shade-producing contacts per insertion)] was 6.218 and 4.51, cluster exposure layer [CEL (number of shading layers between clusters and the nearest canopy boundary)] was 1.90 and 1.04, leaf exposure layer [LEL (number of shading layers between leaves and the nearest canopy boundary)] was 1.16 and 0.78 , cluster exposure flux availability [CEFA (percentage of above-canopy photon flux that reaches the clusters expressed as a decimal)] was 0.03 and 0.14 , and leaf exposure flux availability [LEFA (percentage of above-canopy photon flux that reaches the leaves expressed as a decimal)] was 0.17 and 0.23 in the HWC and LVSP treatments, respectively. Vine spacing did not affect any EPQA metrics. In 2010, root system impacted LLN which was 5.39 and 4.80, PIL which was 62.6 and 58.4, LEL which was 1.06 and 0.89 , LEFA which was 0.19 and 0.21 , and leaf exposure flux symmetry which was 0.00 and -0.03 for grafted and ownrooted treatments, respectively.

Fruit composition. While $\mathrm{pH}$ was 0.1 lower in vines on the HWC compared with LVSP, soluble solids and TA were unaffected by training system in 2009 (Table 1). In 2010, $\mathrm{pH}$ was again lower (by 0.07) in the HWC treatment compared with the LVSP, while soluble solids and TA were unaffected by training system (Table 1). Vine spacing had no impact on fruit composition in either year. Fruit from grafted vines was $0.6 \mathrm{~g} \cdot \mathrm{L}^{-1}$ lower in TA compared with own-rooted vines, while root system had no impact on soluble solids or $\mathrm{pH}$ (Table 1 ).

CONSUMER WINE PREFERENCE. Rank sum analysis for the 2009 vintage indicated that wines produced from the HWC/2.4-m treatment were significantly preferred $(P \leq 0.05)$ to wine produced from the LVSP/1.8-m treatment when wines were evaluated based on aromatic preference. Wines from the two HWC treatments were ranked first and third preferentially, and wines from the two LVSP treatments ranked second and fourth. Analysis of wines produced in 2010 indicated that the wine from the $\mathrm{HWC} / 1.8$-m treatment was significantly preferred $(P \leq$ 0.05 ) to wine produced from LVSP/ 1.8-m, which ranked first and fourth, respectively. All other rank sum results indicated no significant aromatic preferences (Table 3).

\section{Discussion}

The minimal impact of treatments on yield components in 2009 was likely due to vine age; vines had been minimally cropped in their second growing season to encourage vegetative growth, so there was little carryover effect of treatments from the previous growing season. In 2010 , training system, vine spacing, and root system all impacted yield, while pruning weight and crop load ratio were only impacted by training system. EPQA data collected at veraison indicated that the HWC canopy was denser, with lower cluster and leaf exposure than the LVSP system. This observation may partly be a function of unintended leaf removal in the LVSP system occurring when catch wires were moved upwards for VSP. VSP has been repeatedly demonstrated to reduce yield as a result of excessive canopy density in other Vitis hybrid winegrape cultivars (Bordelon et al., 2008; Howell et al., 1987, 1991; Reynolds, 1988; Reynolds and Wardle, 1994; Reynolds et al., 2004) unless the canopy is divided with the Scott Henry system (Bordelon et al., 2008).

In this study, yield per meter of 'Noiret' increased with greater spacing in 2010; this impact of vine spacing on yield differs from the literature on other hybrids where increased spacing (from 1.2 to $2.4 \mathrm{~m}$ ) had limited influence on yield of young 'Chancellor' [Vitis hybrid (Reynolds et al., 1995)], and reduced yield of young 'Seyval blanc' [Vitis hybrid (Reynolds and Wardle, 1994)] and mature 'Seyval blanc' (Reynolds et al., 2004). However pruning weight per meter was considerably lower in those studies compared with the pruning weights reported here for 'Noiret'. Greater pruning weights may indicate that vines in this study were considerably more vegetative than those in comparable studies, a suggestion supported by the exceedingly low crop load ratios reported here ( $\approx 2$ to 4 ) compared with those reported for young 'Chancellor' [5-year average of 11 to 16 (Reynolds et al., 1995)] and young 'Seyval blanc' [5-year average of 18 to 22 (Reynolds and Wardle, 1994)].

Pruning weights in this study averaged $\approx 1.3 \mathrm{~kg} \cdot \mathrm{m}^{-1}$ in 2010 suggesting that 'Noiret' vines can grow much larger than initially reported (Reisch et al., 2006). Yields reported here for HWC were in a similar range as those reported by Reisch et al. (2006), however yield of LVSP was considerably lower than HWC in 2010. Compared with other hybrid pruning weight data reported in the literature, young 'Noiret' in this study was larger than most hybrid winegrape cultivars that are anecdotally considered to be big vines such as 'Chambourcin' [Vitis hybrid (Dami et al., 2006)], 'Traminette' [ Vitis hybrid (Bordelon et al., 2008)], and 
Table 1. Impact of training, vine spacing, and root system on yield components and fruit composition of 'Noiret' winegrape in 2009 and 2010.

\begin{tabular}{|c|c|c|c|c|c|c|c|c|}
\hline Treatment $^{\mathrm{z}}$ & $\begin{array}{c}\text { Yield } \\
\left(\mathrm{kg} \cdot \mathrm{m}^{-1}\right)^{\mathrm{y}}\end{array}$ & $\begin{array}{c}\text { Clusters } \\
(\text { no. } / \mathrm{m})^{\mathrm{y}}\end{array}$ & $\begin{array}{c}\text { Cluster } \\
\text { wt }(\mathrm{kg})^{\mathrm{y}}\end{array}$ & $\begin{array}{c}\text { Pruning } \\
\text { wt }\left(\mathrm{kg} \cdot \mathrm{m}^{-1}\right)\end{array}$ & $\begin{array}{c}\text { Crop load } \\
\text { [yield/pruning } \\
\left.\text { wt }\left(\mathrm{kg} \cdot \mathrm{kg}^{-1}\right)\right]\end{array}$ & $\begin{array}{c}\text { Soluble } \\
\text { solids (\%) }\end{array}$ & $\mathrm{pH}$ & $\begin{array}{c}\text { Titratable } \\
\text { acidity } \\
\left(\mathrm{g} \cdot \mathrm{L}^{-1} \mathrm{TAE}\right)^{\mathrm{x}} \\
\end{array}$ \\
\hline & & & & 2009 & & & & \\
\hline \multicolumn{9}{|l|}{ Training system $(\mathrm{T})$} \\
\hline LVSP & 3.01 & 29.0 & 0.10 & 0.86 & 3.9 & 17.6 & 3.56 & 10.1 \\
\hline HWC & 2.82 & 26.1 & 0.11 & 0.90 & 3.5 & 17.7 & 3.46 & 12.3 \\
\hline $2.4 \mathrm{~m}$ & 2.78 & 24.5 & 0.11 & 0.76 & 3.8 & 17.9 & 3.52 & 11.2 \\
\hline \multicolumn{9}{|l|}{ Combined } \\
\hline LVSP/1.8 m & 3.05 & 30.97 & 0.10 & 0.96 & 3.8 & 17.3 & 3.57 & 9.8 \\
\hline $\mathrm{LVSP} / 2.4 \mathrm{~m}$ & 2.97 & 27.05 & 0.11 & 0.77 & 4.0 & 18.0 & 3.57 & 10.3 \\
\hline $\mathrm{HWC} / 1.8 \mathrm{~m}$ & 3.04 & 30.30 & 0.10 & 1.04 & 3.5 & 17.7 & 3.44 & 12.7 \\
\hline $\mathrm{HWC} / 2.4 \mathrm{~m}$ & 2.60 & 21.86 & 0.12 & 0.76 & 3.6 & 17.7 & 3.47 & 12.0 \\
\hline \multicolumn{9}{|c|}{2010} \\
\hline \multicolumn{9}{|l|}{ Training system } \\
\hline LVSP & 1.91 & 18.2 & 0.10 & 1.07 & 1.9 & 18.3 & 3.62 & 7.8 \\
\hline HWC & 2.89 & 18.6 & 0.16 & 1.23 & 2.7 & 18.2 & 3.55 & 7.4 \\
\hline \multicolumn{9}{|l|}{ Vine spacing } \\
\hline $1.8 \mathrm{~m}$ & 2.24 & 18.3 & 0.12 & 1.17 & 2.1 & 18.3 & 3.60 & 7.7 \\
\hline $2.4 \mathrm{~m}$ & 2.56 & 18.4 & 0.14 & 1.38 & 2.4 & 18.2 & 3.57 & 7.5 \\
\hline \multicolumn{9}{|l|}{ Root system (RS) } \\
\hline Own-rooted & 2.22 & 17.8 & 0.12 & 1.13 & 2.1 & 18.2 & 3.56 & 7.9 \\
\hline Grafted/'101-14 Mgt' & 2.58 & 19.0 & 0.14 & 1.73 & 2.4 & 18.3 & 3.62 & 7.3 \\
\hline \multicolumn{9}{|l|}{ Combined } \\
\hline HWC/grafted & 3.00 & 18.4 & 0.16 & 1.26 & 2.7 & 18.2 & 3.58 & 7.6 \\
\hline $1.8 \mathrm{~m} /$ own-rooted & 2.05 & 17.4 & 0.12 & 1.15 & 1.9 & 18.3 & 3.57 & 8.0 \\
\hline $1.8 \mathrm{~m} / \mathrm{grafted}$ & 2.45 & 19.2 & 0.13 & 1.18 & 2.3 & 18.2 & 3.63 & 7.3 \\
\hline $2.4 \mathrm{~m} /$ own-rooted & 2.39 & 18.1 & 0.13 & 1.11 & 2.3 & 18.0 & 3.55 & 7.7 \\
\hline $2.4 \mathrm{~m} /$ grafted & 2.72 & 18.9 & 0.15 & 1.17 & 2.6 & 18.4 & 3.60 & 7.3 \\
\hline LVSP/1.8 m/own-rooted & 1.52 & 16.5 & 0.10 & 1.10 & 1.5 & 18.2 & 3.60 & 7.9 \\
\hline LVSP $/ 2.4 \mathrm{~m} /$ own-rooted & 1.80 & 16.9 & 0.11 & 1.04 & 1.7 & 18.0 & 3.60 & 7.6 \\
\hline HWC/1.8 m/own-rooted & 2.57 & 18.4 & 0.14 & 1.22 & 2.4 & 18.5 & 3.55 & 8.2 \\
\hline HWC $/ 2.4 \mathrm{~m} /$ own-rooted & 2.97 & 19.3 & 0.16 & 1.17 & 2.9 & 18.1 & 3.50 & 7.8 \\
\hline LVSP / $1.8 \mathrm{~m} /$ grafted & 2.00 & 19.7 & 0.10 & 1.10 & 2.0 & 18.2 & 3.67 & 7.2 \\
\hline LVSP $/ 2.4 \mathrm{~m} /$ grafted & 2.30 & 19.6 & 0.12 & 1.07 & 2.3 & 18.8 & 3.62 & 7.0 \\
\hline $\mathrm{HWC} / 1.8 \mathrm{~m} /$ grafted & 2.88 & 18.7 & 0.15 & 1.27 & 2.6 & 18.3 & 3.60 & 7.5 \\
\hline HWC $/ 2.4 \mathrm{~m} /$ grafted & 3.13 & 18.1 & 0.18 & 1.27 & 2.8 & 18.0 & 3.57 & 7.6 \\
\hline$P$ value $\mathrm{T}$ & $<0.0001$ & 0.6199 & $<0.0001$ & $<0.0001$ & $<0.0001$ & 0.8582 & 0.0279 & 0.0644 \\
\hline$P$ value $S$ & 0.0173 & 0.8727 & $<0.0001$ & 0.4585 & 0.0512 & 0.6827 & 0.3145 & 0.3629 \\
\hline$P$ value RS & 0.0057 & 0.1580 & 0.0049 & 0.2954 & 0.0627 & 0.5848 & 0.0969 & 0.0065 \\
\hline$P$ value $\mathrm{T} \times \mathrm{S}$ & 0.8862 & 0.9996 & 0.5593 & 0.8737 & 0.9126 & 0.1854 & 0.7947 & 0.8731 \\
\hline$P$ value $\mathrm{T} \times \mathrm{RS}$ & 0.3189 & 0.0526 & 0.6932 & 0.4683 & 0.1738 & 0.2045 & 0.7472 & 0.5028 \\
\hline$P$ value $S \times \mathrm{RS}$ & 0.8185 & 0.6035 & 0.4561 & 0.6637 & 0.7401 & 0.3336 & 0.8369 & 0.4181 \\
\hline$P$ value $\mathrm{T} \times \mathrm{S} \times \mathrm{RS}$ & 0.7443 & 0.7687 & 0.4428 & 0.8796 & 0.6427 & 0.4319 & 0.5030 & 0.4634 \\
\hline
\end{tabular}

${ }^{2} \mathrm{LVSP}=$ low cordon with vertical shoot positioning, $\mathrm{HWC}=$ high wire cordon; $1 \mathrm{~m}=3.2808 \mathrm{ft}$.

${ }^{\mathrm{y}} \mathrm{l} \mathrm{kg} \cdot \mathrm{m}-\mathrm{l}=0.6720 \mathrm{lb} / \mathrm{ft}, \mathrm{l}$ cluster $/ \mathrm{m}=0.3048$ cluster $/ \mathrm{ft}, 1 \mathrm{~kg}=2.2046 \mathrm{lb}$.

${ }^{\mathrm{x}} \mathrm{TAE}=$ tartaric acid equivalents; $1 \mathrm{~g} \cdot \mathrm{L}^{-1}=1000 \mathrm{ppm}$. 
Table 2. Impact of training, vine spacing, and root system on canopy architecture of 'Noiret' winegrape in $2010 .^{\mathrm{z}}$

\begin{tabular}{|c|c|c|c|c|c|c|c|c|c|c|c|}
\hline Treatment $^{\mathrm{y}}$ & LLN & PIC & PIL & OLN & CEL & LEL & CCS & CEFA & CEFS & LEFA & LEFS \\
\hline LVSP & 4.33 & 71.9 & 55.1 & 4.51 & 1.04 & 0.78 & 0.40 & 0.14 & 0.65 & 0.23 & -0.04 \\
\hline \multicolumn{12}{|l|}{ Vine spacing $(S)$} \\
\hline $1.8 \mathrm{~m}$ & 5.16 & 85.8 & 60.1 & 5.43 & 1.54 & 0.99 & -0.07 & 0.07 & -0.02 & 0.20 & -0.01 \\
\hline $2.4 \mathrm{~m}$ & 5.03 & 79.8 & 60.1 & 5.26 & 1.40 & 0.96 & 0.12 & 0.10 & 0.04 & 0.20 & -0.02 \\
\hline Grafted/'101-14 Mgt' & 5.39 & 85.4 & 62.6 & 5.65 & 1.53 & 1.06 & -0.01 & 0.07 & -0.27 & 0.19 & 0.00 \\
\hline \multicolumn{12}{|l|}{ Combined } \\
\hline LVSP/1.8 m & 4.40 & 77.6 & 55.6 & 4.60 & 1.20 & 0.79 & 0.15 & 0.11 & 0.29 & 0.22 & -0.02 \\
\hline $\mathrm{LVSP} / 2.4 \mathrm{~m}$ & 4.26 & 66.2 & 54.7 & 4.43 & 0.88 & 0.78 & 0.66 & 0.17 & 1.00 & 0.23 & -0.06 \\
\hline $\mathrm{HWC} / 1.8 \mathrm{~m}$ & 5.93 & 94.0 & 66.3 & 6.27 & 1.90 & 1.19 & -0.28 & 0.03 & -0.34 & 0.17 & 0.01 \\
\hline HWC/grafted & 6.28 & 92.1 & 68.4 & 6.61 & 1.92 & 1.28 & -0.34 & 0.04 & -0.91 & 0.16 & 0.03 \\
\hline $1.8 \mathrm{~m} /$ own-rooted & 4.83 & 80.0 & 58.4 & 5.13 & 1.46 & 0.88 & 0.03 & 0.10 & 0.49 & 0.21 & -0.04 \\
\hline $1.8 \mathrm{~m} /$ grafted & 5.50 & 91.7 & 63.5 & 5.74 & 1.61 & 1.10 & -0.16 & 0.04 & -0.54 & 0.19 & 0.02 \\
\hline $2.4 \mathrm{~m} /$ own-rooted & 4.78 & 80.6 & 58.4 & 4.97 & 1.35 & 0.89 & 0.11 & 0.10 & 0.09 & 0.21 & -0.02 \\
\hline $2.4 \mathrm{~m} /$ grafted & 4.29 & 79.1 & 61.8 & 5.55 & 1.45 & 1.02 & 0.13 & 0.10 & 0.00 & 0.20 & -0.02 \\
\hline LVSP/1.8 m/own-rooted & 5.28 & 63.5 & 59.0 & 4.24 & 0.95 & 0.68 & 0.38 & 0.18 & 0.84 & 0.24 & -0.06 \\
\hline LVSP $/ 2.4 \mathrm{~m} /$ own-rooted & 4.27 & 66.7 & 54.8 & 4.45 & 0.92 & 0.77 & 0.62 & 0.17 & 1.00 & 0.23 & -0.06 \\
\hline HWC/1.8 m/own-rooted & 5.64 & 96.4 & 64.6 & 6.02 & 1.98 & 1.09 & -0.32 & 0.02 & 0.15 & 0.18 & -0.02 \\
\hline $\mathrm{HWC} / 2.4 \mathrm{~m} /$ own-rooted & 5.28 & 94.4 & 62.3 & 5.50 & 1.78 & 1.01 & -0.41 & 0.03 & -0.83 & 0.19 & 0.02 \\
\hline LVSP / $1.8 \mathrm{~m} /$ grafted & 4.77 & 91.7 & 59.0 & 4.96 & 1.45 & 0.91 & -0.08 & 0.04 & -0.25 & 0.21 & 0.02 \\
\hline LVSP $/ 2.4 \mathrm{~m} /$ grafted & 4.25 & 65.7 & 54.5 & 4.42 & 0.83 & 0.79 & 0.70 & 0.17 & 1.00 & 0.23 & -0.06 \\
\hline$P$ value $\mathrm{T} \times \mathrm{S} \times \mathrm{RS}$ & 0.2304 & 0.0921 & 0.1579 & 0.1560 & 0.1246 & 0.3203 & 0.1735 & 0.1009 & 0.8096 & 0.1434 & 0.2029 \\
\hline
\end{tabular}

${ }^{z} \mathrm{LLN}=$ leaf layer number, PIC = percent interior clusters, $\mathrm{PIL}=$ percent interior leaves, $\mathrm{OLN}=$ occlusion layer number, $\mathrm{CEL}=\mathrm{cluster}$ exposure layer, $\mathrm{LEL}=\mathrm{leaf}$ exposure layer, $\mathrm{CCS}=$ canopy cluster symmetry, CEFA = cluster exposure flux availability, CEFS = cluster exposure flux symmetry, LEFA = leaf exposure flux availability, LEFS = leaf exposure flux symmetry.

${ }^{y}$ LVSP $=$ low cordon with vertical shoot positioning, $\mathrm{HWC}=$ high wire cordon; $1 \mathrm{~m}=3.2808 \mathrm{ft}$.

'Vidal' [ Vitis hybrid (Howell et al., 1987)]. However, 'Corot noir' (Vitis hybrid) grown in the Finger Lakes region of New York can exceed 'Noiret' in vine size (Sun et al., 2012), as can 'Chancellor' in BC, Canada, in some growing seasons (Reynolds et al., 2004).

Crop load ratios in this study were slightly lower than those reported for Reisch et al. (2006) for their New York planting (3.8) and were considerably lower than crop load ratios reported for 'Noiret' in Vincennes, IN (7.5), and West Lafayette, IN (6.4), over a 6- and 10 -year period, respectively (Reisch et al., 2006). Although the cultivar release bulletin suggested that cluster thinning may be helpful in some years
(Reisch et al., 2006) the young vines in this study were overly vegetative and did not produce enough fruit, as evidenced from the low crop load ratios (average of 1.9 to 2.7 in 2010). While there is no specific recommendation for crop load ratio for 'Noiret' or for hybrids in general, recommendations have ranged from 8 to 12 (Bordelon et al., 2008) although considerably higher crop load ratios have been maintained with no detrimental impacts on fruit quality in 'Seyval blanc' (Berkey et al., 2011; Reynolds et al., 2004), 'Chancellor' (Reynolds et al., 2004), and 'Marechal Foch' [ Vitis hybrid (Sun et al., 2011)]. Management practices to increase the crop load ratio of 'Noiret' should be investigated.
In concordance with results reported here, previous hybrid training studies generally suggest minimal impacts of training on fruit composition (Bordelon et al., 2008; Howell et al., 1987; Wolpert et al., 1983) unless a divided system such as Geneva Double Curtain (GDC) is used (Morris et al., 1984; Reynolds and Wardle, 1994; Reynolds et al., 1995). Vine spacing had no impact on fruit composition, a result similar to previous studies (Reynolds and Wardle, 1994; Reynolds et al., 1995, 2004).

The significant preference of the panel for the aroma of an HWC wine compared with the aroma of a LVSP wine in both years, combined with the lower yield and crop load ratio reported 
Table 3. Rank sum analysis for consumer preference of 2009 and 2010 'Noiret' wines produced from vines in a training/spacing experiment grafted onto '101-14 Mgt' rootstock.

\begin{tabular}{|c|c|}
\hline Treatment $^{\mathrm{z}}$ & Rank sum ${ }^{\mathrm{y}}$ \\
\hline \multicolumn{2}{|c|}{2009} \\
\hline $\mathrm{HWC} / 2.4 \mathrm{~m}$ & $51 \mathrm{a}$ \\
\hline $\mathrm{HWC} / 1.8 \mathrm{~m}$ & $66 \mathrm{ab}$ \\
\hline $\mathrm{LVSP} / 2.4 \mathrm{~m}$ & $60 \mathrm{ab}$ \\
\hline LVSP/1.8 m & $82 \mathrm{~b}$ \\
\hline
\end{tabular}

2010

\begin{tabular}{ll} 
HWC $/ 2.4 \mathrm{~m}$ & $62 \mathrm{ab}$ \\
$\mathrm{HWC} / 1.8 \mathrm{~m}$ & $54 \mathrm{a}$ \\
LVSP $/ 2.4 \mathrm{~m}$ & $66 \mathrm{ab}$ \\
LVSP $/ 1.8 \mathrm{~m}$ & $78 \mathrm{~b}$ \\
\hline
\end{tabular}

${ }^{2} \mathrm{HWC}=$ high wire cordon, LVSP $=$ low cordon with vertical shoot positioning, 1.8 and $2.4 \mathrm{~m}$ indicate spacing between vines; $1 \mathrm{~m}=3.2808 \mathrm{ft}$.

'Rank sum totals followed by different letters are significant at $P<0.05$.

for the LVSP in 2010 compared with the HWC, suggests that the preference for the HWC wines may be a function of the higher crop load ratio. Alternatively, the higher OLN, higher CEL, and lower CEFA reported for HWC compared with LVSP may suggest that shaded clusters of 'Noiret' produce more appealing aromatic profiles when fermented.

We found the LVSP on $1.8-\mathrm{m}$ vine spacing to be exceedingly difficult to manage because of the general propensity of 'Noiret' vines to grow large leaves and produce persistent laterals. The LVSP canopies required multiple hedging passes (minimum of three passes in each growing season) as shoots would grow over the top catch wire and then downward resulting in complete coverage of the fruiting zone with downward growing shoots. In addition, the raising of catch wires in the LVSP system generally resulted in unintended but significant leaf removal as the foliage was so dense and confined. Although our intention was for this study to be a longterm one, the excessive vegetativeness of vines in the $1.8-\mathrm{m}$ spacing treatment was so great that every other vine was removed from the $1.8-\mathrm{m}$ vine spacing treatment in the study in early 2011 to investigate the impact of $3.6-\mathrm{m}$ vine spacing with this cultivar.

\section{Conclusion}

'Noiret' produces large vines, with pruning weights of young vines exceeding most reported for hybrid winegrape cultivars in the literature. Crop load ratios on all vines in the study were extremely low, suggesting the cultivar has a vegetative growth habit and that management practices to increase crop load ratio need to be investigated. Although this study reports only 2 years of data collected in a young vineyard, these early results provide the first guidance on choosing a training system and vine spacing for 'Noiret' and suggest that the inherent vigor and downward growth habit of the cultivar make it unsuitable for training to a vertically shootpositioned system in the early years of the vineyard. In addition, the increased yield and tendency toward higher crop load ratio reported in the 2.4- $\mathrm{m}$ spacing treatment compared with the $1.8 \mathrm{-m}$ spacing treatment suggests that greater vine spacing should be considered for 'Noiret' when planning vineyards. While measureable fruit composition was not greatly impacted by training, vine spacing, and root system treatments, the consumer wine panel preferred the aroma of an HWC wine to the LVSP/1.8- $\mathrm{m}$ wine in both years of the study.

\section{Literature cited}

Basker, D. 1988. Critical values of differences among rank sums for multiple comparisons. Food Technol. 42:79-84.

Berkey, T.G., A.K. Mansfield, S.D. Lerch, J.M. Meyers, and J.E. Vanden Heuvel. 2011. Crop load adjustment in 'Seyval blanc': Impacts on yield components, fruit composition, consumer wine preferences, and economics of production. HortTechnology 21:593-598.

Bordelon, B.P., P.A. Skinkis, and P.H. Howard. 2008. Impact of training system on vine performance and fruit composition of Traminette. Amer. J. Enol. Viticult. 59:39-46.

Dami, I., D. Ferree, A. Prajitna, and D. Scurlock. 2006. A five-year study on the effect of cluster thinning on yield and fruit composition of 'Chambourcin' grapevines. HortScience 41:586-588.

Howell, G.S., D.P. Miller, C.E. Edson, and R.K. Striegler. 1991. Influence of training system and pruning severity on yield, vine size, and fruit composition of Vignoles grapevines. Amer. J. Enol. Viticult. 42:191-198.

Howell, G.S., T.K. Mansfield, and J.A. Wolpert. 1987. Influence of training system, pruning severity and thinning on yield, vine size, and fruit quality of Vidal blanc grapevine. Amer. J. Enol. Viticult. 38:105-112.
Joanes, D.N. 1985. On a rank sum test due to Kramer. J. Food Sci. 50:1442.

Kramer, A. 1956. A quick rank test for significance of differences in multiple comparisons. Food Technol. 10:392.

Meyers, J.M. and J.E. Vanden Heuvel. 2008. Enhancing the precision and spatial acuity of point quadrat analyses via calibrated exposure mapping. Amer. J. Enol. Viticult. 59:425-431.

Morris, J.R., C.A. Sims, J.E. Bourque, and J.L. Oakes. 1984. Influence of training system, pruning severity, and spur length on yield and quality of six FrenchAmerican hybrid grape cultivars. Amer. J. Enol. Viticult. 35:23-27.

Reisch, B.I., R.S. Luce, B. Bordelon, and T. Henick-Kling. 2006. 'Noiret' grape. New York State Agr. Expt. Sta. Bul. 160.

Reynolds, A.G. 1988. Response of Okanagan Riesling vines to training system and simulated mechanical pruning. Amer. J. Enol. Viticult. 39:205-212.

Reynolds, A.G. and D.A. Wardle. 1994. Impact of training system and vine spacing on vine performance and berry composition of Seyval blanc. Amer. J. Enol. Viticult. 45:444-451.

Reynolds, A.G., D.A. Wardle, and A.P. Naylor. 1995. Impact of training system and vine spacing on vine performance and berry composition of Chancellor. Amer. J. Enol. Viticult. 46:88-97.

Reynolds, A.G., D.A. Wardle, M.A. Cliff, and M. King. 2004. Impact of training system and vine spacing on vine performance, berry composition, and wine sensory attributes of Seyval and Chancellor. Amer. J. Enol. Viticult. 55:84-95.

Reynolds, A.G. and J.E. Vanden Heuvel. 2009. Influence of grapevine training systems on vine growth and fruit composition: A review. Amer. J. Enol. Viticult. 60:251-268.

Sun, Q.L., G.L. Sacks, S.D. Lerch, and J.E. Vanden Heuvel. 2011. Canopy microclimate and time of harvest impacts fruit composition and wine quality of Marechal Foch. Amer. J. Enol. Viticult. 62:32-41.

Sun, Q.L., G.L. Sacks, S.D. Lerch, and J.E. Vanden Heuvel. 2012. Shoot thinning and cluster thinning impact yield, fruit composition, and wine quality of Corot noir. Amer. J. Enol. Viticult. 63:49-56.

Wolpert, J.A., G.S. Howell, and T.K. Mansfield. 1983. Sampling Vidal Blanc grapes: 1. Effect of training system, pruning severity, shoot exposure, shoot origin, and cluster thinning on cluster weight and fruit quality. Amer. J. Enol. Viticult. 34: 72-76. 